\title{
Soil Health as Influenced by Fertilizer Management in Rice Based Cropping System
}

\author{
M M Haque ${ }^{*}$, M R Islam¹, MS Rahman², M A R Sarkar³, M AA Mamun , M U Salam5 and M S Kabir ${ }^{6}$
}

\begin{abstract}
Nutrient management influences soil health and crop productivity. Sustained crop production requires specific nutrient management options after a certain period. The objectives of this investigation were to examine the effects of inorganic and organic fertilization on yields and soil carbon budget under rice based cropping patterns in Bangladesh. The research data and information have been generated based on previously published, unpublished sources and own concept. Omission of $\mathrm{K}$ or imbalanced $\mathrm{K}$ are more influential for reduction in grain yield up to $47 \%$ in Boro (dry) season but $\mathrm{N}$ was most limiting up to $35 \%$ in T. Aman (wet) season. With existing fertilizer rates for growing rice, the balances of $\mathrm{N}$ and $\mathrm{K}$ are always negative. Balanced chemical fertilizer (NPKSZn) can be an option for improving crop productivity and maintain soil quality. Net ecosystem carbon (C) balances are positive when $3 \mathrm{t} \mathrm{ha}^{-1}$ cow dung (CD), $2 \mathrm{t} \mathrm{ha}^{-1}$ poultry manure (PM) and $2 \mathrm{t} \mathrm{ha}^{-1}$ vermicompost (VC) are used in combination with chemical fertilizers. Soil amendments with organic nutrient sources (rice straw, CD, PM, VC, legume crops) and rice based cropping patterns such as T. Aman-Mustard-Boro, Boro-Fallow-Fallow, Jute-T. Aman-Fallow, Wheat-Mungbean-T. Aman, Grass pea- T. Aus-T. Aman and Potato-Boro-T. Aman can be beneficial in improving soil C budget, soil nutrient ratio, total crop production and maintenance of environmental health that will meet SDGs goal.
\end{abstract}

Key words: Nutrient omissions, yield reduction, cropping pattern, organic nutrient sources, rice.

\section{INTRODUCTION}

The average yield of rice has been stagnant and remained lower than the production potential, which might be due to the imbalanced use of fertilizers. Excessive or inappropriate use of chemical, among others, fertilizers is a major cause of nutrient imbalance in soil. Continuous rice culture using sole chemical fertilizer reduces soil quality, carbon sequestration and rice productivity (Haque et al., 2019a, c). In such situations, chemical and organic nutrient sources and agronomic management system could be important management options to improve rice productivity and soil quality (Timsina, 2006 and Sihi et al., 2017). Huge amounts of chemical fertilizers are generally used by the farmers in Bangladesh, although not in balanced proportion (Biswas et al., 2008). The continuous chemical and imbalanced fertilization are considered to be the main issue of rice productivity decline in Bangladesh (Saleque et al., 2004). Rice productivity trends were declining in many long-term fertilization experiments under double rice cultures and also in non-rice based double or triple cropping systems (Haque et al., 2019a, 2015b and Yadvinder et al., 2005). Rice-Fallow-Rice is the most dominant cropping pattern in Bangladesh covering about $27 \%$ of the cropland (Nasim et al., 2017). The reduction in grain yields was mostly related to a gradual decline in soil nutrients status, soil organic carbon (SOC) content, poor agronomic management practices adopted by the farmers, pest and disease infestation, and changes in the biochemical and physical properties of soil organic matter (SOM) (Haque et al., 2015a and Timsina et al., 2018). We hypothesize that fertilizer management with varied nutrient combinations influences soil carbon sequestration and rice productivity.

Agricultural management practices such as use of cover crop biomass, farmyard manure, green manure, poultry litter, mustard oil cake, vermicompost, etc not only supply plant

\footnotetext{
1Soil Science Division, Bangladesh Rice Research Institute (BRRI), Gazipur-1701, Bangladesh; 2Plant Physiology Division, BRRI, Gazipur-1701, Bangladesh; ${ }^{3}$ Agricultural Economics Division, BRRI, Gazipur-1701, Bangladesh; ${ }^{4}$ Agricultural Statistics Division, BRRI, Gazipur-1701, Bangladesh; ${ }^{5}$ Freelance International Consultant (Agricultural Systems), Bangladesh; ${ }^{6}$ Director General, BRRI, Gazipur-1701, Bangladesh.

${ }^{*}$ Corresponding author's E-mail: mhaquesoil @ yahoo.com (M M Haque)
} 
nutrients; but also affect SOC contents, aggregate stability, water holding capacity, bulk density and finally grain yields (Haque et al., $2019 b$ ). It is necessary to assess rice productivity and soil health to sustain rice production as well as soil fertility and to formulate an effective adaptation strategy to minimize yield reduction (Kabir et al., 2020). Food security analysis is important for highly populated and limited cropland areas like Bangladesh that face natural hazards every year. The outputs from such analysis can be utilized by the policy planners to prioritize research and/or to emphasize intensive production in favourable regions. Previous studies mention that only chemical fertilizer application showed negative net carbon balance during rice cultivation (Sihi et al., 2017 and Haque et al., 2019b). Therefore, the objectives of this investigation were to find out the suitable nutrient management options for sustained crop production and net ecosystem carbon budget and development and mapping the action plan for three decades on reducing yield loss from the fertilizer management in rice soil of Bangladesh.

\section{MATERIALS AND METHODS}

\section{Experimental design and fertilization}

The experiment was initiated on a permanent layout at the BRRI farm, Gazipur, Bangladesh in 1985. Twelve treatments in randomized complete block design (RCB design) with four replications were imposed (Haque et al., 2019a). However, we have considered only NPKSZn, PKSZn (-N), NKSZn (-P), NPSZn ($\mathrm{K})$, NPKZn (-S), NPKS (-Zn) and control treatments for our analyses and interpretations of findings. Since organic amendments (Cow dung, poultry manure and vermicompost) were used from 2009 to 2019, we have taken those treatments for comparison of rice yield performances with chemical fertilizers. In Boro (dry) season, NPKSZn @ 120-25-35-20-5 kg ha-1 was used but in wet season (rainfed wet season) it was 100-25-35-20-5 kg ha-1 during 19852008. After 2008, NPKSZn was used @ 138-1080-5-5 kg ha-1 and 100-10-80-5-5 kg ha-1, for Boro and T. Aman seasons, respectively based on the soil test. In 2009-2010 dry season, organic materials were used with $+\mathrm{PK}$, $+\mathrm{SZn}$, +KSZn, +PSZn and +PKSZn treatments. Nitrogen as urea, $\mathrm{P}$ as triple super phosphate, $\mathrm{K}$ as muriate of potash, $\mathrm{S}$ as gypsum and $\mathrm{Zn}$ as zinc chloride were used as inorganic nutrient sources. Organic nutrient sources used for selected treatments were vermicompost (VC, $2 \mathrm{t}$ $\left.\mathrm{ha}^{-1}\right)$, cow dung $\left(\mathrm{CD}, 3 \mathrm{t} \mathrm{ha} \mathrm{a}^{-1}\right)$, poultry manure (PM, $2 \mathrm{t} \mathrm{ha}^{-1}$ ) in +PSZn, +KSZn, and +PKSZn treatments. Only N @ 138 kg ha-1 was applied as top dress in organic nutrient added plots. Table 1 shows nutrient composition of organic materials.

During 1985-2008, BR3 and BR11 were used as indicator rice varieties in Boro and $\mathrm{T}$. Aman seasons, respectively. From 2009 onward BRRI dhan29 and BRRI dhan49 were used in Boro and T. Aman seasons, respectively. Rice was transplanted in the first week of January and harvested in May for Boro season and $\mathrm{T}$. Aman rice was transplanted in the first week of August and harvested in the third week of November. Two to three rice seedlings (45-50-day-old in dry season and 25-35-dayold in wet season) were transplanted at $20-x$ 20-cm spacing.

Table 1. Nutrient compositions of cow dung, poultry manure and vermicompost.

\begin{tabular}{llllll}
\hline Organic material & $\% \mathrm{~N}$ & $\% \mathrm{P}$ & $\% \mathrm{~K}$ & $\% \mathrm{~S}$ & $\% \mathrm{Zn}$ \\
\hline Cow dung & 0.51 & 0.15 & 0.50 & 0.00 & 0.00 \\
Poultry manure & 1.90 & 0.56 & 0.75 & 1.10 & 0.02 \\
Vermicompost & 2.00 & 0.52 & 0.42 & 0.30 & 0.03 \\
\hline
\end{tabular}

120 Haque et al. 
Urea $\mathrm{N}$ was applied in three equal splits at final land preparation, active tillering stage, and 5-7 days before panicle initiation (PI) stage equally for both seasons. Rest of the fertilizers were applied at final land preparation. The crop was harvested at maturity and grain yield was recorded at $14 \%$ moisture content and straw yield as oven dry basis.

\section{Carbon balance}

Soil organic carbon (SOC) stock was determined as follows: SOC stock $=$ SOC ${ }^{*}$ soil depth*bulk density

\section{Action plan development}

Consultant opinion has been used for making the action plan for better fertilizer management and rice yield production during 20212050.

\section{RESULTS AND DISCUSSIONS}

\section{Changes in rice productivity and nutrient balance}

Inorganic chemical fertilizer treatment (NPKSZn) produced significantly $(\mathrm{P}<0.05)$ higher mean grain yield than omissions of selected nutrients in both T. Aman and Boro seasons (Table 2).
Omission of sulfur (S) in both seasons had positive response for higher grain yields including $\mathrm{Zn}$ in only dry season. There was around $26 \%$ yield advantage in Boro season compared to T. Aman season, but no significant straw yield differences between the seasons for the same treatment. Grain yield reductions because of $\mathrm{N}, \mathrm{P}$ and $\mathrm{K}$ were more prominent in Boro season than in T. Aman season (Fig. 1). In general, grain yield reductions in Boro season varied from $25-45 \%, 2-40 \%$, and 2$47 \%$ for $\mathrm{N}, \mathrm{P}$ and $\mathrm{K}$, respectively might be because of the climate effect. Similarly, in T. Aman season, yield reductions were 5-35\%, 2$15 \%$, and $3-22 \%$ for $\mathrm{N}, \mathrm{P}$ and $\mathrm{K}$ omissions, respectively. Nitrogen and $\mathrm{K}$ balance were negative in both the seasons but $\mathrm{P}$ balance was positive except for $\mathrm{P}$ omission and control treatments (Figs. 2 and 3).

\section{Inorganic and organic nutrient sources on yield}

Continuous application of different $C$ sources increased grain yield than complete chemical fertilization during 2010-2019. In conventional complete chemical fertilization, grain yields were in static position; but grain yield increasing trends were higher with organic nutrient sources (Fig. 4).

Table 2. Grain and straw yields of rice as influenced by fertilizer management under a Rice-Fallow-Rice cropping system for 35 years in BRRI, Gazipur.

\begin{tabular}{lcccc}
\hline \multirow{2}{*}{ Treatment } & \multicolumn{2}{c}{ T. Aman season } & \multicolumn{2}{c}{ Boro season yield (t ha- $\left.{ }^{-1}\right)$} \\
\cline { 2 - 5 } & Grain & Straw & Grain & Straw \\
\cline { 2 - 5 } & $4.28 \mathrm{a}$ & $5.25 \mathrm{a}$ & $5.35 \mathrm{a}$ & $5.40 \mathrm{a}$ \\
NPKSZn & $3.56 \mathrm{c}$ & $4.38 \mathrm{~b}$ & $3.26 \mathrm{c}$ & $3.35 \mathrm{c}$ \\
PKSZn (-N) & $3.93 \mathrm{~b}$ & $4.87 \mathrm{a}$ & $3.95 \mathrm{~b}$ & $4.54 \mathrm{~b}$ \\
NKSZn (-P) & $3.56 \mathrm{c}$ & $4.79 \mathrm{a}$ & $3.92 \mathrm{~b}$ & $4.47 \mathrm{~b}$ \\
NPSZn (-K) & $3.86 \mathrm{~b}$ & $5.24 \mathrm{a}$ & $5.22 \mathrm{a}$ & $5.16 \mathrm{a}$ \\
NPKZn (-S) & $4.24 \mathrm{a}$ & $5.11 \mathrm{a}$ & $5.22 \mathrm{a}$ & $5.23 \mathrm{a}$ \\
NPKS (-Zn) & $3.05 \mathrm{~d}$ & $3.60 \mathrm{c}$ & $2.34 \mathrm{~d}$ & $2.65 \mathrm{~d}$ \\
Control & &
\end{tabular}

Note: Means within each row followed by same letter do not differ significantly at $\mathrm{P}<0.05$ level using Tukey's HSD test. Source: Haque et al., 2019a; BRRI Annual Research Review, 2019 


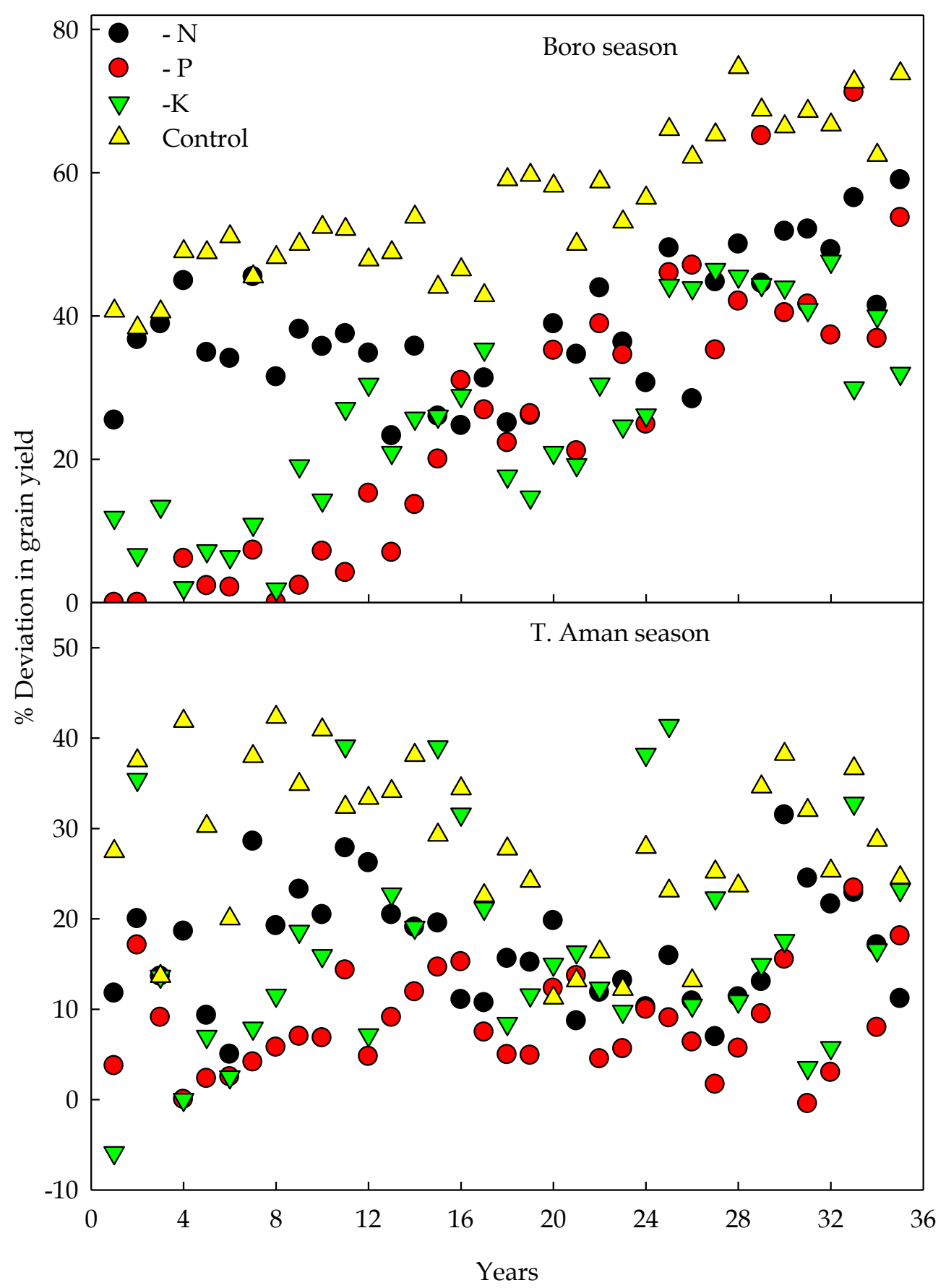

Fig. 1. Percentage changes in grain yields because of omissions of N, P, K compared to NPKSZn fertilization during 19852019, BRRI, Gazipur, Bangladesh (Haque et al., 2019a; BRRI Annual Research Review, 2019). 


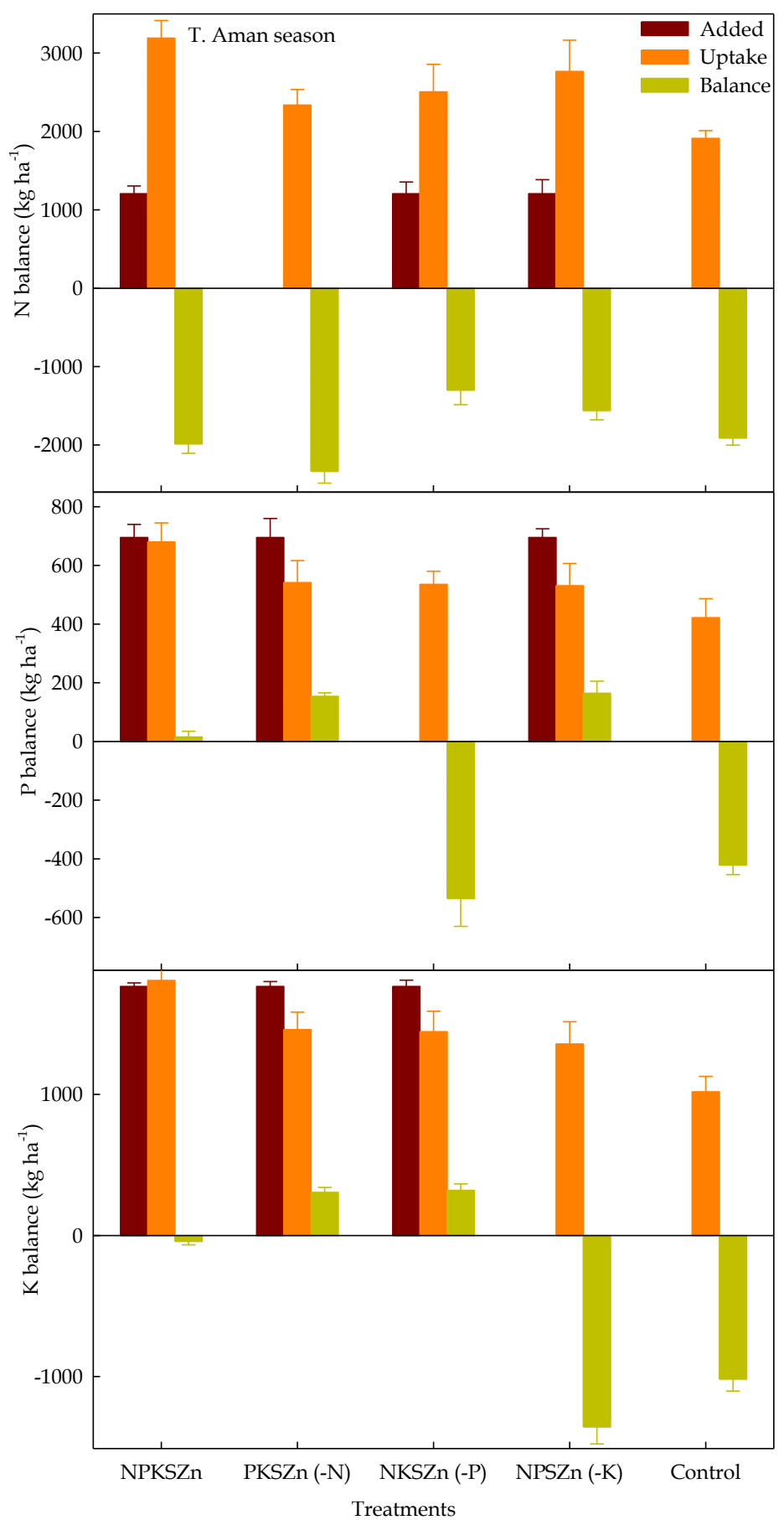

Fig. 2. Changes in mean N, P and K nutrient balances after 35 years of fertilization under Rice-Fallow-Rice cropping system in wet season. [Bars indicate mean value \pm standard error $(n=3)$. (Haque et al., 2019a; BRRI Annual Research Review, 2019)]. 


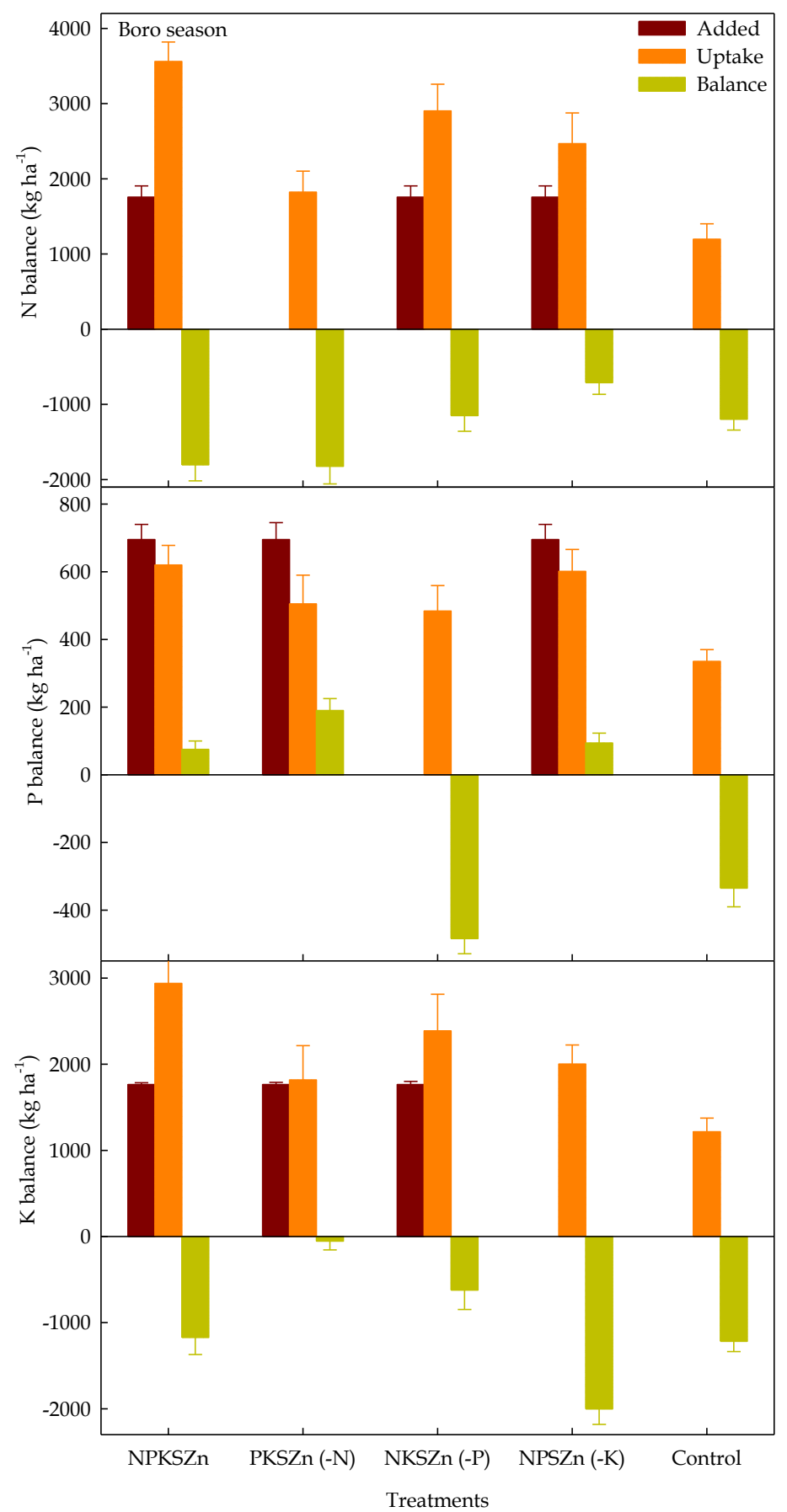

Fig. 3. Changes in mean N, P and K nutrient balances after 35 years of fertilization under Rice-Fallow-Rice cropping system in Boro season. [Bars indicate mean value \pm standard error $(n=3)$. (Haque et al., 2019a; BRRI Annual Research Review, 2019)] 


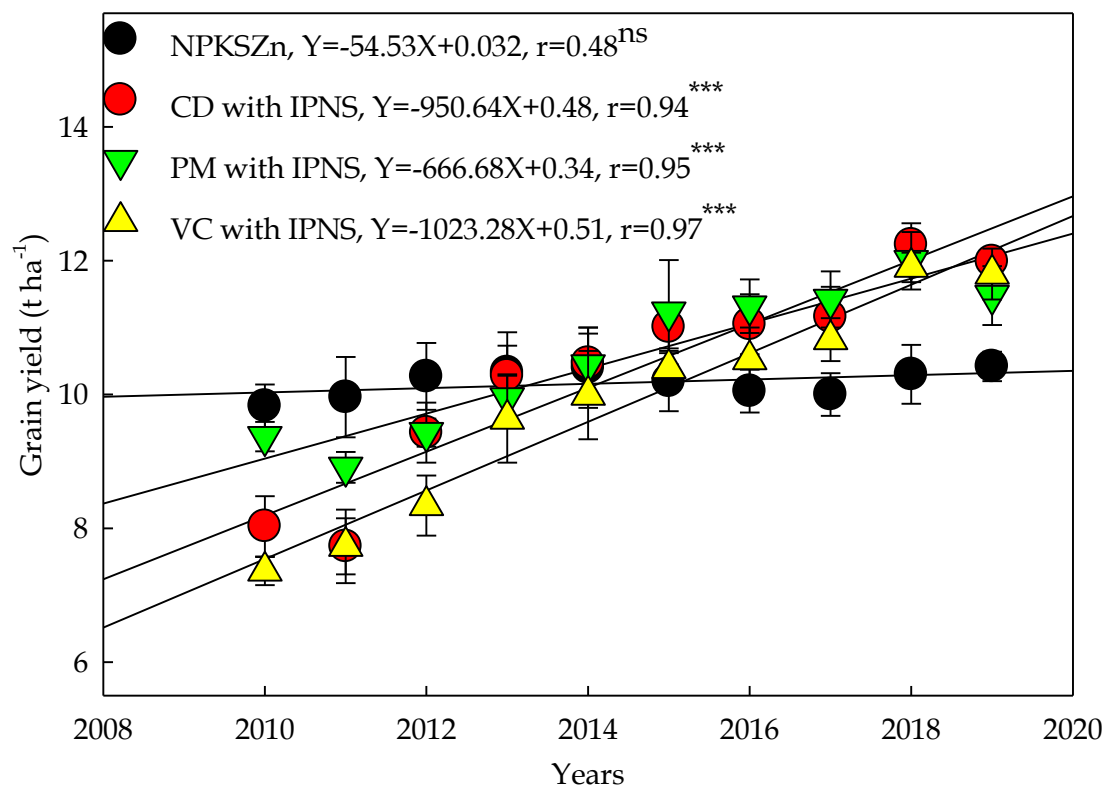

Fig. 4. Changes in annual rice yield under inorganic and organic amendments for 10 years. [Bars indicate mean value \pm standard error $(\mathrm{n}=3)$; ns and ${ }^{* * *}$ mean non-significant and significant at $\mathrm{P} \leq 0.001$, respectively]. [Note: $\mathrm{CD}$ with IPNS = Cowdung with integrated plant nutrient system, Poultry manure (PM), vermicompost (VC) (Haque et al., 2019a; BRRI Annual Research Review, 2019)].

Rice productivity and nutrient use-efficiency varied significantly $(\mathrm{P}<0.05)$ under inorganic fertilization over the seasons for 35 years in Rice-Fallow-Rice cropping pattern because of varietal differences and weather variations. Average rice productivity with NPKSZn treatment was about 5.35 and $4.28 \mathrm{tha}^{-1}$ in Boro and T. Aman seasons, respectively. It would be necessary to increase such yield levels to 8.0 $\mathrm{t} \mathrm{ha} \mathrm{A}^{-1}$ by 2030 to meet the rice demand in Bangladesh. To do so, we have to cultivate nutrient use-efficient varieties along with the adoption of proper nutrient management systems. Although $\mathrm{N}$ is the most limiting nutrient to improve rice grain yield in Bangladesh including other Asian countries, $\mathrm{P}$ and $\mathrm{K}$ deficiencies also play antagonistically against higher yields. There is widespread mining of $K$ in Bangladesh along with emerging new nutrient deficiencies (Biswas et al., 2017) that should be addressed for sustained rice production in Bangladesh. We have also found negative con- tributions of $\mathrm{N}, \mathrm{P}$ and $\mathrm{K}$ if not used rationally (Fig. 1). However, global concerns are about the over use of inorganic fertilizers that impair environments (Laegreid et al., 1999) and contribute to soil acidity and contaminates the ground water resources (Bijai et al., 2008). In solving such a dilemma, the use of indigenous nutrients and added ones should be tuned up depending on crop requirements. As rice productivity was declining under fixed fertilizer management in a Rice-Fallow-Rice system, new avenues of nutrient management options were investigated to improve rice productivity. After 35 years, K balance was 1350 to $320 \mathrm{~kg} \mathrm{ha}^{-1}$ in wet season and -60 to $2000 \mathrm{~kg} \mathrm{ha}^{-1}$ for dry season.

\section{Organic matter and different nutrient defi- ciency status}

About $35-79 \%$ of areas are deficit based on major nutrient elements and organic matter in different regions of Bangladesh (SRDI, 2020). There- 
fore, many management practices are needed to recover the nutrient status as well as increased yield productivity in Bangladesh (Table 3).

\section{Soil properties and net carbon budget}

Continuous rice cultivation without fertilization for 35 years significantly $(\mathrm{P}<0.05)$ deteriorated studied soil chemical properties except for $\mathrm{P}$ status (Table 4). Continuous $\mathrm{P}$ applications significantly $(\mathrm{P}<0.05)$ increased total and available soil $\mathrm{P}$ contents. In the control treatment, $C$ balance was significantly negative ($101 \mathrm{~kg} \mathrm{C} \mathrm{ha-1,} \mathrm{p<0.05)} \mathrm{compared} \mathrm{to} \mathrm{the} \mathrm{other}$ treatments after 35 years in Rice-Fallow-Rice systems; but the magnitude of such negative balance was almost half (-60 kg C ha-1) when NPKSZn fertilizers were added (Fig. 5). Among the organic nutrient sources, $C$ balance did not vary significantly through $C$ sequestration which was about $94-95 \mathrm{~kg} \mathrm{C} \mathrm{ha-1}^{-1}$.

The negative $C$ balance can be improved through the adoption of different cropping patterns. For example, $\mathrm{C}$ balance was positive with
T. Aman-Mustard-Boro and Jute-T. AmanFallow patterns (Fig. 6). The SOC is generally low in soils of Bangladesh. So, the continuous addition of CD and PM with IPNS fertilization for nine years increased SOC balance (Fig. 5). Addition of organic $\mathrm{C}$ alleviated soil health and thus there was higher $C$ sequestration because most of the $\mathrm{C}$ added from organic sources were in recalcitrant forms. The addition of organic nutrient sources can also help in reducing the amounts of inorganic fertilizers for rice production. Moreover, choice of suitable cropping pattern(s) would be necessary not only to diversify crop production but also to improve $C$ sequestration. Besides, greenhouse gas emissions in relation to inorganic fertilizer production can be reduced through the use of organic nutrient sources and based on patterns and varieties. So, policy intervention and improved dissemination techniques for the application of organic nutrient sources should be strengthened not only for increased rice production but also to maintain soil fertility.

Table 3. Deficit soil nutrient status of Bangladesh.

\begin{tabular}{lccl}
\hline Nutrient status & Area (lac ha) & Percentage $(\%)$ & Optimum value \\
\hline Phosphorus & 66.0 & 44.7 & $8 \mathrm{ppm}$ \\
Potassium & 52.7 & 35.7 & 0.12 meq $^{-1} 100 \mathrm{~g}$ soil \\
Sulfur & 65.3 & 44.2 & $10 \mathrm{ppm}$ \\
Zinc & 55.5 & 37.6 & $0.6 \mathrm{ppm}$ \\
Boron & 51.5 & 34.6 & $0.2 \mathrm{ppm}$ \\
Organic matter & 116.4 & 78.9 & Up to $5 \%$ \\
\hline
\end{tabular}

Source: SRDI, 2020

Table 4. Soil properties as influenced by fertilizer management after harvesting of 35 years of nutrient amendment, Bangladesh Rice Research Institute, Gazipur, Bangladesh.

\begin{tabular}{lccccc}
\hline Parameter & Initial & \multicolumn{3}{c}{ Treatment } \\
\cline { 3 - 6 } & & NPKSZn & PKSZn & NKSZn & NPSZn \\
\hline pH $(1: 5$ with H $2 \mathrm{O})$ & 6.78 & $6.96 \mathrm{a}$ & $6.67 \mathrm{~b}$ & $6.71 \mathrm{~b}$ & $6.76 \mathrm{~b}$ \\
Organic carbon $\left(\mathrm{g} \mathrm{kg}^{-1}\right)$ & 12.2 & $11.8 \mathrm{a}$ & $11.9 \mathrm{a}$ & $11.8 \mathrm{a}$ & $11.9 \mathrm{a}$ \\
Total $\mathrm{N}\left(\mathrm{g} \mathrm{kg}^{-1}\right)$ & 0.08 & $0.12 \mathrm{a}$ & $0.10 \mathrm{a}$ & $0.11 \mathrm{a}$ & $0.11 \mathrm{a}$ \\
Total $\mathrm{P}\left(\mathrm{mg} \mathrm{kg}^{-1}\right)$ & - & $346 \mathrm{c}$ & $449 \mathrm{a}$ & $137 \mathrm{~d}$ & $420 \mathrm{~b}$ \\
Olsen $\mathrm{P}\left(\mathrm{mg} \mathrm{kg}^{-1}\right)$ & 9.8 & $22 \mathrm{~b}$ & $30 \mathrm{a}$ & $3 \mathrm{c}$ & $22 \mathrm{~b}$ \\
Total K $\left(\mathrm{g} \mathrm{kg}^{-1}\right)$ & - & $4.25 \mathrm{a}$ & $3.81 \mathrm{~b}$ & $4.17 \mathrm{a}$ & $3.67 \mathrm{c}$ \\
Exchangeable K & 70 & $54 \mathrm{a}$ & $54 \mathrm{a}$ & $50 \mathrm{~b}$ & $38 \mathrm{c}$ \\
$\left(\mathrm{mg} \mathrm{kg}^{-1}\right)$ & & & & & \\
\hline
\end{tabular}

Note: Means within each row followed by same letter do not differ significantly at $\mathrm{P}<0.05$ level using Tukey's HSD test. Source: Haque et al., 2019a

126 Haque et al. 


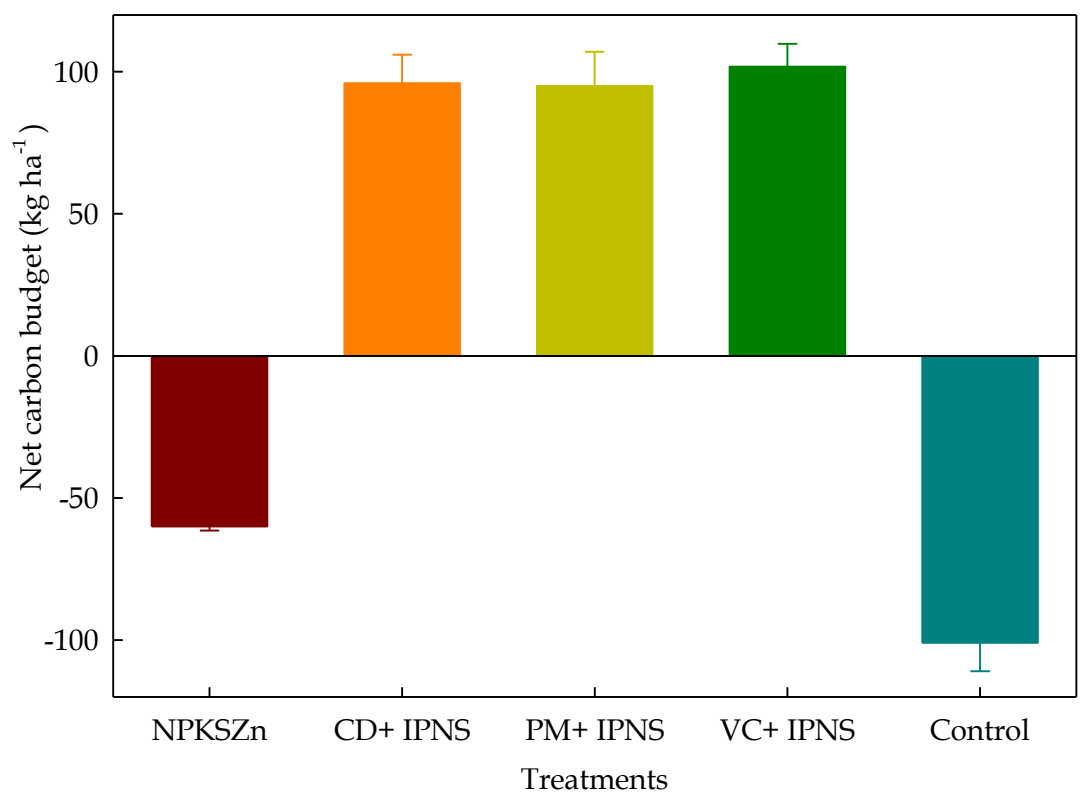

Fig. 5. Soil organic carbon stock and its budget as influenced by organic and inorganic amendments, BRRI, Gazipur, Bangladesh. Note: $C D+I P N S=$ Cowdung with integrated plant nutrient system, Poultry manure $(\mathrm{PM})$, vermicompost (VC) (Haque et al., 2019a). Net carbon budget = Total input carbon-Total output carbon.

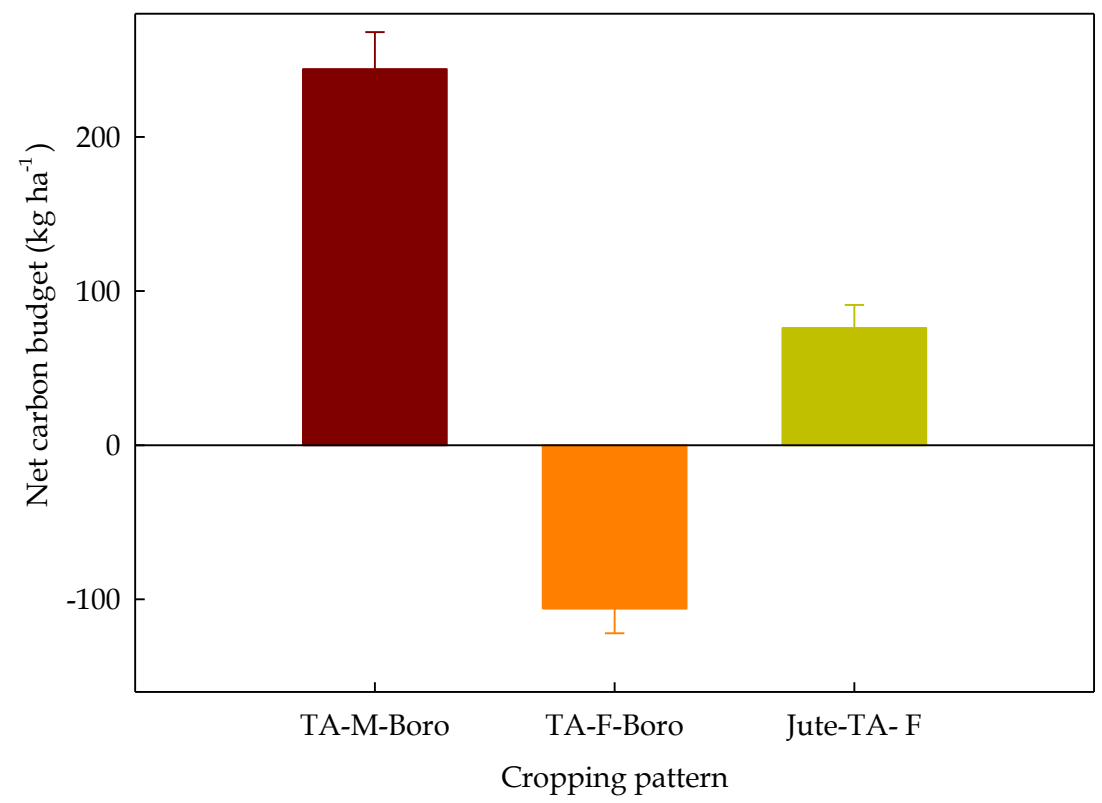

Fig. 6. Net carbon balance as influenced by cropping patterns at farmer's field, Kishoreganj, Bangladesh. [Note: TA-MBoro=T. Aman-Mustard-Boro, TA-F-Boro= T. Aman-Fallow-Boro, Jute-TA-F= Jute-T. Aman-Fallow (Haque et al., 2020)]. 


\section{Action plan}

Management strategies will be helpful for maintaining soil carbon balance as well as crop productivity at the farmer's level. The yield target will depend on different fertilizer management practices in different regions of Bangladesh (Fig. 7).

The nutrient composition will be determined based on selection of nutrient composition (Table 5) during the study period. Action plan activities will be undertaken for conscious build up with balanced chemical fertilizer application, ensuring any kinds of organic fertilizer sources, retaining crop residue (such as rice straw up to $25-30 \mathrm{~cm}$ incorporated into rice soil), nano chemical fertilizer application, slow-release fertilizer application (Nymph coated, sulfur coated, etc.), leguminous crops incorporation, training arrangd for the amenities of organic and inorganic fertilizer uses to the farmers and extensions personal for awareness of soil carbon balance and increased crop production (Table 6).

Yield target

Approach

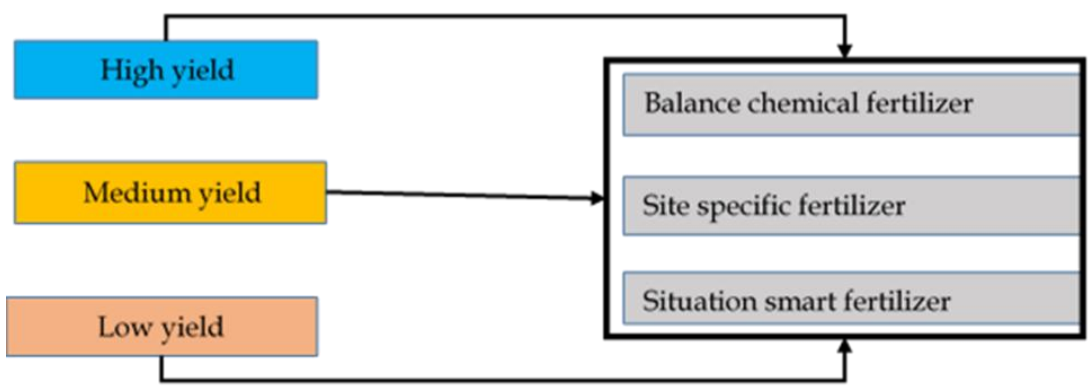

Fig. 7. Yield target based different fertilizer management.

Table 5. Selection of nutrient composition will be influenced under inorganic and organic fertilizer management.

\begin{tabular}{|c|c|c|}
\hline Theme & & Activity \\
\hline \multirow{2}{*}{$\begin{array}{l}\text { Nutrient } \\
\text { composition }\end{array}$} & Inorganic & Organic \\
\hline & $\begin{array}{l}\text { - Ackage mix fertilizer } \\
\text { - Nutrient composition } \\
\text { - Nano chemical fertilizer } \\
\text { - Slow-release chemical fertilizer }\end{array}$ & $\begin{array}{l}\text { - Retain crop residue (such as rice straw up to } 25-30 \mathrm{~cm} \\
\text { incorporated into rice soil) } \\
\text { - Ensure any kinds of organic fertilizer requirement } \\
\text { - Leguminous crops incorporation }\end{array}$ \\
\hline
\end{tabular}

Table 6. Action plan strategies will be helpful for maintaining soil carbon balance and crop productivity.

\begin{tabular}{|c|c|c|c|c|c|}
\hline Theme & Programme & $2021-2030$ & \multicolumn{2}{|c|}{$2031-2040$} & $2041-2050$ \\
\hline \multirow{4}{*}{$\begin{array}{l}\text { Research and } \\
\text { development }\end{array}$} & $\begin{array}{l}\text { Yield target-based fertilizer } \\
\text { management }\end{array}$ & Continue improving & Follow up & $\begin{array}{l}\text { Continue } \\
\text { improving }\end{array}$ & Follow up \\
\hline & Nutrient composition & Continue improving & Follow up & $\begin{array}{l}\text { Continue } \\
\text { improving }\end{array}$ & Follow up \\
\hline & Net carbon balance & \multicolumn{4}{|c|}{ Continue improving } \\
\hline & Reduce atmosphere $\mathrm{CO}_{2}$ & \multicolumn{4}{|c|}{ Continue improving } \\
\hline \multirow{3}{*}{ Extension } & $\begin{array}{l}\text { Training for farmers and } \\
\text { extension personal }\end{array}$ & \multicolumn{4}{|c|}{ Continue } \\
\hline & Field demonstration & \multicolumn{4}{|c|}{ Continue } \\
\hline & Promotional activities & \multicolumn{4}{|c|}{ Continue } \\
\hline
\end{tabular}




\section{System recommendation}

The action plan will be implemented through the system recommendation process. System recommendation is one of the important techniques for increasing yield productivity as well as maintaining good soil health (Fig. 8). The major steps for mapping and understanding the system recommendation are (i) system identification based on cropping pattern, soil and land typology, and agro-ecosystem; (ii) technology innovation, testing, and calibration; and (iii) validation. The whole process will be evaluated and executed through field survey, field experience, research and development on cropping pattern, land typology and ecosystem, field trial and feedback. Therefore, systematic implementation of the system recommendation will help for reducing production costs and increased economic benefit to the farmers under different agro-ecological zones of Bangladesh.

\section{CONCLUSION}

Different types of organic fertilizer sources can be considered as one of the best management options for increasing rice productivity and soil carbon balance. Continuous omissions of $\mathrm{N}, \mathrm{P}, \mathrm{K}, \mathrm{S}$, and $\mathrm{Zn}$ reduced grain yields compared to NPKSZn fertilization with variable ranges depending on the growing season. The influence of $\mathrm{N}, \mathrm{P}, \mathrm{K}, \mathrm{S}$ and $\mathrm{Zn}$ omissions on grain yield was in the order of $\mathrm{N}>\mathrm{K}>\mathrm{P}>\mathrm{S}>\mathrm{Zn}$ in Aman season and that of $\mathrm{K}>\mathrm{N}>\mathrm{P}>\mathrm{S}>\mathrm{Zn}$ in Boro season indicating that season specific nutrient rate adjustment, balanced chemical fertilizer, and organic fertilizers would be required for sustained rice production and soil health in Bangladesh. Action plan will be helpful for

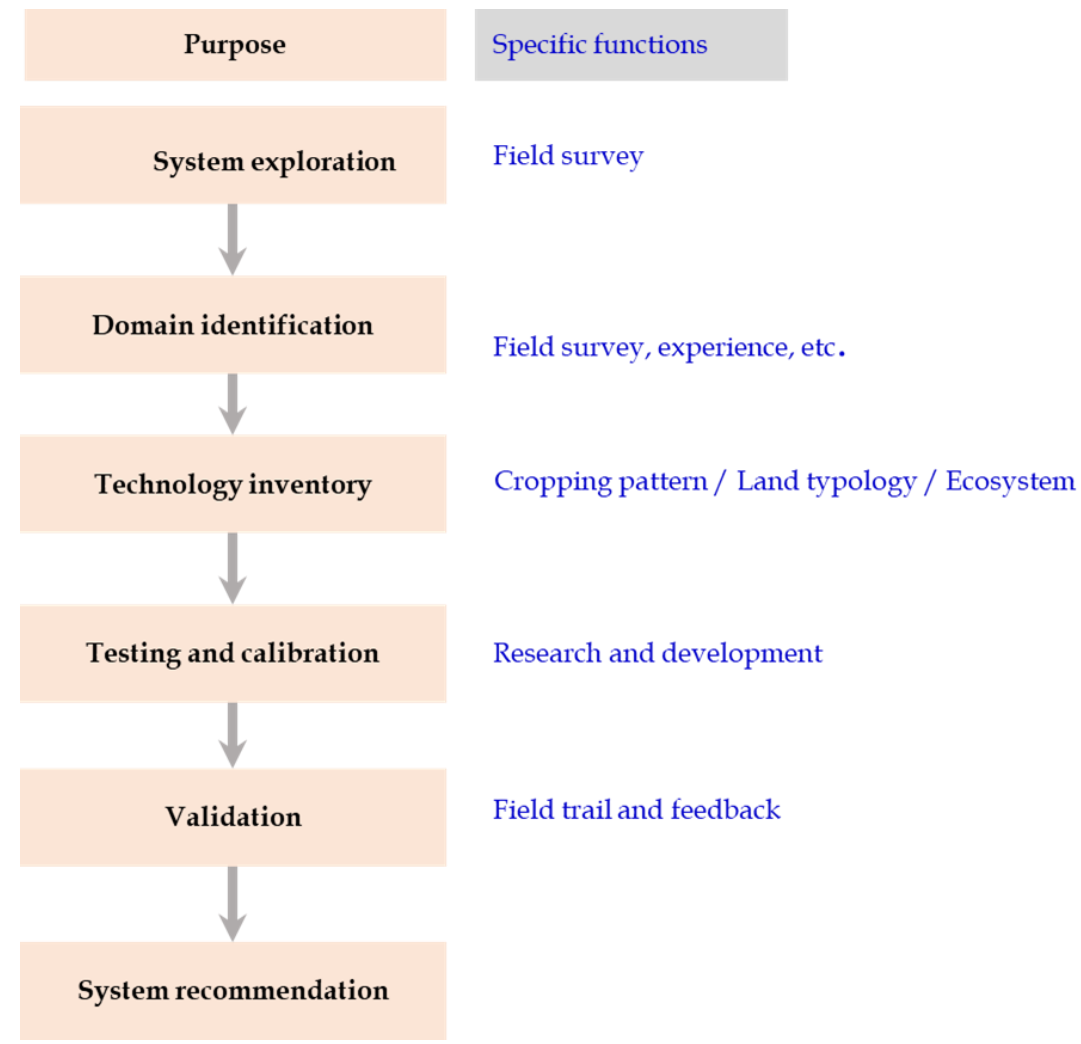

Fig. 8. Some activities will be helpful for making system recommendation. 
enhancing productivity and minimizing production costs. Balanced chemical fertilizer, organic amendments, and adoption of rice-based cropping patterns can be beneficial in maintaining soil carbon balance and total crop production along with maintenance of environmental health that will meet SDG's target.

\section{ACKNOWLEDGMENTS}

The authors wish to thank anonymous reviewers for their suggestions, which significantly improved this article.

\section{AUTHORS' CONTRIBUTION}

MMH, MUS, and MSK generated idea; MARS and MAAM coordinated the research; $\mathrm{MMH}$ developed methodology; MMH, MRI, MSR, MARS, MUS and MSK provided scientific insights; MMH gathered data, carried out analysis and synthesis; MMH did the writings for all versions of the manuscript; MSK, MUS, MSR, MARS and MAAM performed critical review and editing. All authors read and approved the final manuscript.

\section{DECLARATION OF INTERESTS}

A version of the paper was published in a book 'Doubling Rice Productivity in Bangladesh' in 2020 by the Bangladesh Rice Research Institute (BRRI), Gazipur 1701, Bangladesh to commemorate BRRI's 50th anniversary. The Bangladesh Rice Journal has prior knowledge of the book publication and does not see any conflict of interest.

\section{REFERENCES}

Biswas, J C, M M Haque and P K Saha. 2017. Rice yield potential under unfavorable soil ecosystems in Bangladesh. Asian Journal of Soil Science and Plant Nutrition, 1: 1-10.

Biswas, J C, M Maniruzzaman, M A Sattar and M G Neogi. 2008. Improvement of rice yield through fertilizer and cultural management at farmer's field. Bangladesh Rice Journal, 13: 9-14.

BRRI (Bangladesh Rice Research Institute). 2019. Longterm effect of organic and inorganic nutrients on yield and yield trend of lowland rice. Annual re-

130 Haque et al. search review workshop 2018-19. Soil Science Division, Bangladesh Rice Research Institute, Gazipur. 24pp, 36pp, 43pp.

Haque, M M and J C Biswas. 2020. Effect of long-term chemical fertilization on rice productivity and soil fertility. Springer Nature, Book chapter. https://doi.org/10.1007/978-981-15-6953-1_8.

Haque, M M, J C Biswas, M R Islam, A Islam and M S Kabir. 2019a. Effect of long-term chemical and organic fertilization on rice productivity, nutrient use efficiency, and balance under a rice- fallow- rice system. Journal of Plant Nutrition, 42: 2901-2914.

Haque, M M, J C Biswas, M Akter, M Maniruzaman and M $S$ Kabir. 2019b. Carbon budget and aggregate stability of paddy soil under continuous organic amendment. Communication in Soil Science and Plant Analysis, 50: 1829-1837.

Haque, M M, A L Saha, J C Biswas, M R Islam, A Islam and U A Naher. 2019c. Effect of missing nutrient elements on grain yield of wet season rice in Bangladesh. American Journal of Plant Sciences, 10: 631-639.

Haque, M M, M A Saleque, A L Shah, J C Biswas and P J Kim. 2015b. Long-term effect of sulfur and zinc fertilization on rice productivity and nutrient efficiency in double rice cropping paddy in Bangladesh. Communication in Soil Science and Plant Analysis, 46: 2877-2887.

Haque, M M, M A Saleque and A L Shah. 2015c. Effect of Long-Term Fertilization on Rice Productivity and Nutrient Efficiency under Double Cropping System. Aperito Journal of Biochemistry and Biochemical Techniques, 1: 1-12.

Kabir, M S, M U Salam, A K M S Islam, M A R Sarkar, M A A Mamun, M C Rahman, B Nessa, M J Kabir, H B Shozib, M B Hossain, A Chowdhury, M Nasim, K M Iftekharuddaula, M S Hossain, M K A Bhuiyan, B Karmakar, MS Rahman, M M Haque, M T Khatun, M P Ali, S M H A Rabbi, P L Biswas, E S M H Rashid and N M F Rahman. 2020. Doubling rice productivity in Bangladesh: A way to achieving SDG2 and moving forward. Bangladesh Rice Journal, 24 (2) : 1-47.

Laegreid, M, O C Bockman and O Kaarstad. 1999. Agriculture, Fertilizers and the Environment. CABI, Wallingford, UK, 294p.

Nasim, M, S M Shahidullah, A Saha, M A Muttaleb, T LAditya, M A Ali and M S Kabir. 2017. Distribution of crops and cropping patterns in Bangladesh. Bangladesh Rice Journal, 21: 1-55.

Saleque, M A, M J Abedin, N I Bhuiyan, S K Zaman and G M Panaullah. 2004. Long-term effects of inorganic and organic fertilizer sources on yield and nutrient 
accumulation of lowland rice. Field Crops Research, 86: 53-65.

Sihi, D, B Dari, D K Sharma, H Pathak, L Nain and O P Sharma. 2017. Evaluation of soil health in organic vs. conventional farming of basmati rice in North India. Journal of Plant Nutrition Soil Science, 180:389-406.

Singh, B. 2008. Crop demand driven site specific nitrogen applications in rice and wheat: some recent advances. Indian Journal of Agronomy, 53: 1-30.

SRDI (Soil Resource Development Institute). 2020. World soil day 2020 sovenir. Soil Resource Development Institute, farmgate, Dhaka.

Timsina, J, G M Panaullah, M A Saleque, M Ishaque, A B M B U Pathan, M A Quayyum, D J Connor, P K Sa- ha, E Humphreys and C A Meisner. 2006. Nutrient Uptake and Apparent Balances for Rice-Wheat Sequences. I. Nitrogen. Journal of Plant Nutrition, 29: 137-155.

Timsina, J, J Wolf, N Guilpart, L G J van Bussel, P Grassini, $\mathrm{J}$ van Wart, A Hossaind, H Rashid, S Islam and M K van Ittersum. 2018. Can Bangladesh produce enough cereals to meet future demand? Agricultural Systems, 163: 36-44.

Yadvinder, S, S Bijay and J Timsina. 2005. Crop residue management for nutrient cycling and improving soil productivity in rice-based cropping systems in the tropics. Advances in Agronomy, 85: 269-407. 
132 Haque et al. 